\title{
FACTOR ANALYSIS, RELIABILITY AND VALIDITY OF A MEASUREMENT MODEL FOR THE INTENT OF ALCOHOL CONSUMPTION AMONG ECUADORIAN TEENAGERS
}

\section{ANÁLISIS FACTORIAL, CONFIABILIDAD Y VALIDEZ DE UN MODELO DE MEDICIÓN PARA LA INTENCIÓN DE CONSUMO DE ALCOHOL ENTRE ADOLESCENTES ECUATORIANOS}

\author{
Rodrigo Moreta-Herrera' ${ }^{1}$, Marlon Mayorga-Lascano ${ }^{1}$, Aitor Larzabal-Fernandez¹ \& Diego Vaca-Quintana² \\ ${ }^{1}$ Pontificia Universidad Católica del Ecuador, Ambato. Ecuador \\ 2Universidad Tecnológica Indoamérica. Ecuador
}

\section{Abstract}

Objective. Confirm the bifactorial structure, reliability and validity of the Modelo de Medición de Intención al consumo de Alcohol (MMICA), in a sample of Ecuadorian adolescents. Method. Instrumental study with factor analysis, reliability and validity (construct and criterion) of the MMICA among risky and not risky consumers. The sample was 480 students ( $52.3 \%$ men), between 12 to 19 years $(M=14.8, S D=1.5)$, from three different educational centres (67.9\% public) of Ambato and Pelileo cities, Ecuador. Results. The bifactorial structure is confirmed with a variance explained of $72.1 \%$, the adjustment data are adequate with $X^{2}=39.9 ; \mathrm{p}<.001 ; \mathrm{df}=26 ; X^{2} / \mathrm{df}=1.5 ; \mathrm{CFI}=$ .98; TLI= .97; SRMR= .045; RMSEA=.048 [.011 - .077]. Reliability is high ( $\omega=.90$ for behavioural control and $\omega=$, 84 for behavioural belief). This study confirms criterion validity between risky and not risky alcohol consumers. Conclusions. The MMICA is an adequate, reliable and valid test to assess intent of alcohol consumption among Ecuadorian adolescents.

Keywords: Adolescent, alcohol, consumption, factor analysis, intention.

\section{Resumen}

Objetivo. Confirmar la estructura bifactorial, la confiabilidad y validez del Modelo de Medición de Intención al Consumo de Alcohol (MMICA), en una muestra de adolescentes ecuatorianos. Método. Estudio instrumental con análisis factorial, confiabilidad y validez (constructo y criterio) del MMICA entre consumidores riesgosos y no riesgosos. La muestra fue de 480 estudiantes (52.3\% hombres), entre 12 y 19 años ( $M=$ $14.8, S D=1.5)$, de tres centros educativos diferentes (67.9\% público) de las ciudades de Ambato y Pelileo, Ecuador. Resultados. La estructura bifactorial se confirma con una variación explicada del 72,1\%, los datos de ajuste son adecuados con $X^{2}=39.9 ; \mathrm{p}<.001 ; \mathrm{df}=26 ; X^{2} / \mathrm{df}=1.5$; $\mathrm{CFI}=.98 ; \mathrm{TLI}=.99 ; \mathrm{SRMR}=.045 ; \mathrm{RMSEA}=.048$ [.011 - .077]. La confiabilidad es alta $(\omega=.90$ para el control conductual y $\omega=.84$ para la creencia conductual). Este estudio confirma la validez de criterio entre los consumidores de alcohol arriesgados y no arriesgados. Conclusiones. El MMICA es una prueba adecuada, confiable y válida para evaluar la intención del consumo de alcohol entre los adolescentes ecuatorianos.

Palabras clave: Adolescente, alcohol, consumo, análisis factorial, intención. 
Alcohol consumption is a widespread practice among teenagers, making this a public health problem worldwide (World Health Organization [WHO], 2014). Physical, social and psychological problems produced by alcohol abuse raise concern in society and a heavy burden for governments due to high budgets invested in public health systems to develop prevention programs and providing treatment (Kuntsche, Kuntsche, Thrul \& Gmel, 2017).

Latin America is one of the regions in the world with the highest frequency of alcohol consumption among adolescents. Average age for onset of consumption is 14 years old and although the frequency of consumption is lower than in adults, the amount of alcohol consumed in each intake is bigger (Moreta-Herrera, Almache-Moya, Vargas-Espín \& Vaca-Quintana, 2019; Pan American Health Organization [PAHO], 2015). Data of alcohol consumption in Ecuadorian teenagers shows that frequency of alcohol use is slightly lower compared to other countries of the region. Studies at national level, as well as other empirical studies (Consejo Nacional de Control de Sustancias Estupefacientes y Psicoactivos [CONSEP], 2013; Moreta-Herrera, Mayorga-Lascano, León-Tamayo, \& Ilaja-Verdesoto, 2018a; Paqui Baho, 2017) show that alcohol consumption has a prevalence of $20 \%$ to $30 \%$ within the last month, with alcohol being the substance with highest consumption among adolescents.

Given that alcohol consumption is embedded in adolescents' daily practices, it is important for Psychology to develop explanatory models of this practice in order to have better understanding of the underlying mechanisms of this behaviour, hoping to gather strong evidence that might help in future prevention and intervention procedures. Within the aforementioned explanatory models, Theory of Planned Behaviour (TPB) holds solid empirical evidence as a predictive model of health behaviours based on socio-cognitive criteria (Ajzen, 1985; Ajzen \& Fishbein, 2000).

According to this theory, behavioural intention precedes behaviour (Mankarious \& Kothe, 2015). Similarly, this intention, is established by attitudes (positive or negative evaluations of a behaviour), subjective norm (perception of social approval of a behaviour) and perceived behavioural control (perception of the ease or difficulty of performing a behaviour) (Conner \& Sparks, 2015; Fishbein \& Ajzen,
2010). Consequently, all expressed behaviour has a degree of cognitive processing and planning prior to its execution, even if conscious is mediating or not the process.

Previous research employs TPB to understand the behavioural dynamics of substance abuse in general (Dempsey et al., 2016; Guzmán Facundo, García Salas, Aguilar, \& Alonso Castillo, 2014; Moreta-Herrera, IlajaVerdesoto, Mayorga-Lascano, León-Tamayo \& LópezCastro, 2018b); as well as in alcohol consumption (Norman, 2011; Norman, Webb \& Millings, 2019; Peltzer, Conde, Biscarra, Lichtenberger \& Cremonte, 2017). Evidence shows that socio-cognitive components within TPB predicts the development of alcohol consumption's behaviour (Mankarious \& Kothe, 2015).

Behavioural intention is a key factor on the initiation and cessation of tobacco use (Durán, Rodríguez, Ferraces, Río \& Sabucedo, 2016) and alcohol consumption (Glock \& Krolak-Schwerdt, 2013; Hasking \& Schofield, 2015). Preliminary data establish that behavioural intention towards alcohol consumption explains the variance of behaviour by about 29\% (Broadwater, Curtin, Martz \& Zrull, 2006; Cooke, Dahdah, Norman, \& French, 2016). This is a key aspect, because modification of intention will change the variability of behaviours related to health and alcohol consumption (Sheeran et al., 2016). Increase in perception of real risk changes behavioural intention, mainly due to the way in which health warnings are provided to adolescents. Previous research has shown that pictorial health warnings that generate fear responses increases both perception of real risk and behavioural intention towards reducing and quitting alcohol consumption (Wigg \& Stafford, 2016).

Assessment of behavioural intention towards consumption, supported by widely known assessment tools with strong empirical evidence, is a long overdue debt within psychological research. Research and development in this line of work is poor in Latin America, reflected on the scarcity of exploratory and confirmatory studies of the hypotheses used in papers designed to adapt and validate measurement test in this context.

\section{Evaluation of intention towards alcohol consumption}

As mentioned above, research on alcohol consumption is limited by the lack of objective measurement tests to assess alcohol consumption itself 
and other related variables, such as behavioural intention to consume. Absence of proper assessment tools in this area produces measurement errors (bias) and internal validity problems within studies (Dominguez-Lara, Merino-Soto \& Navarro-Loli, 2018; Hox, Moerbeek \& Van de Schoot, 2017). Lack of a correct calibration of assessment tools is counterproductive, since results becomes distorted and directly affects in diagnosis, research and intervention (Caycho, 2017).

Given the importance of behavioural intention as a subjective factor that might lead to alcohol consumption (Cooke, Dahdah, Norman, \& French, 2016; Glock \& KrolakSchwerdt, 2013), a reliable assessment tool for this component is essential for the progress in this research line; this will allow a broader understanding of alcohol consumption phenomenon and the development of intervention strategies and resources. One of the few test in Spanish used to assess intention of consumption is the Modelo de Medición de Intención al Consumo de Alcohol [MMICA] (Vera Noriega, Tánori Quintana, Valdés Cuervo, Martínez Ortega \& Martínez, 2014). Which is a short and specific version for measuring intention towards alcohol consumption following the guidelines of Rodríguez-Kuri, Diaz-Negrete, Gracia-Gutiérrez de Velasco, GuerreroHuesca and Gómez-Maqueo (2007).

The MMICA is constructed with a bifactorial model that includes Perceived Behavioural Control (Perceived ability to act in a certain way in a given situation); and Behavioural Beliefs (beliefs about consequence of a behaviour) (Vera Noriega et al., 2014).

This assessment tool holds strong evidence for reliability and validity to assess intention toward substance consumption in Mexican adolescents. Variance explained is about $66.1 \%$, distributed in $50.1 \%$ and $16.1 \%$ for factors 1 and 2 respectively. In addition, the two-factor model has an adequate fit with values of $\chi^{2}=35.4 ; p<.05$; $d f=26 ; \chi^{2} / d f=1.36 ; \mathrm{CFI}=.998 ; \mathrm{NFI}=.993 ; \mathrm{GFI}=.991$; RMSEA $=.028$. Internal consistency of referential test is $a=.9$.

While it is true that MMICA is validate in the Mexican context, it is unknown whether the test can be applied or not in other cultural contexts such as the Ecuadorian one. If the results are similar, a reliable tool will be available to assess intention improving the development of research of the phenomenon of alcohol consumption in the country and probably in the region.

\section{Objectives and hypotheses}

The first objective of the study is to confirm the bifactorial model of MMICA (Vera Noriega et al., 2014) in a sample of adolescents, since one of the hypothesis is that the adjustment will be appropriate for Ecuadorians. The last aim is to identify the reliability and criterion validity of the test; since the final hypothesis is that, the instrument is reliable and has criterion validity among consumers of alcohol with risk and without risk.

\section{METHOD}

\section{Design and participants}

The present work covers a quantitative instrumental study (Ato, López \& Benavente, 2013) confirming the bifactorial structure of the MMICA, reliability, validity of construct and criterion among risky and not risky alcohol consumers in a sample of Ecuadorian teenagers.

The sample corresponds to 480 adolescents, 52.3\% men and $47.7 \%$ women. Age ranged from 12 to 19 years $(M=14.8 ; S D=1.5)$. A $67.9 \%$ of the participants lives in Ambato city and the remaining $32.1 \%$ lives in Pelileo, Province of Tungurahua, Ecuador; likewise $70.8 \%$ reside in urban sector and $29.2 \%$ in rural sector. A $26.5 \%$ of the sample defines its socioeconomic status as "regular" and "bad". Teenagers from the sample comes from three educational centres, $67.9 \%$ and $32.1 \%$ belonging to public and private schools respectively.

Selection of participants was carried out through non-probabilistic sampling with the following inclusion criteria: a) voluntary participation; b) authorization and written consent by legal representative; c) student currently enrolled in authorized educational centres; and d) regular attendance to classes.

\section{Instruments}

Modelo de medición de la Intención hacia el Consumo de Alcohol (MMICA, Vera Noriega et al., 2014). Designed to assess the intention of alcohol consumption based on beliefs and behaviours around alcohol and its consumption. The test consists of nine items measured on a Likert scale of five options, where one corresponds to "strongly disagree" and five to "strongly agree". The scale is composed of two factors that include: a) 
Behavioural control and b) Behavioural beliefs. Although a normative scale is not yet found, generally the higher the score, the higher the level of intention towards alcohol consumption.

\section{Procedure}

After authorization from educational centres and legal caregivers, researchers carry on by informing students about the objectives of the study and an invitation to participate on it. The assessment was carried out in classrooms with an approximately 20 minute's duration. Data collection was done in a single moment due to the cross-sectional nature of this research. Subsequently, evaluation team organized the information and set the results in a database for statistical analysis. Publication commission of Pontificia Universidad Católica del Ecuador Sede Ambato (PUCESA) reviewed and approved the execution of ethics guidelines for this research.

\section{Data analysis}

This study includes three blocks of statistical analysis. The first one is a descriptive analysis of the items to know the response dynamics of the participants. The assumption of univariate normality it is identified when kurtosis and skewness scores are within the threshold \pm 1.5 (Pérez \& Medrano, 2010). Multivariate normality was also verified through Mardia test, in order to select the appropriate statistical techniques for proper factor analysis (Cain, Zhang \& Yuan, 2017; Mardia, 1970).

Second block of analysis corresponds to factorial structure. Sample was previously segmented into two working groups to ensure that results are independent or 'non-representative' (Ferrando \& Anguiano-Carrasco, 2010). First group with 231 cases was submitted to Exploratory Factor Analysis (EFA), to know the factorial structure of the MMICA. Analyses before EFA included Kaiser-Meyer-Olkin (KMO) test for sample adequacy, homogeneity of variance test (Bartlett) and commonality. EFA analysis included factor extraction using Unweighted Least Squares Method (ULS) with polichoric correlations and Promin rotation, since this research has ordinal variables and multivariate normality assumption is not met (Lorenzo-Seva, 1999). This procedure helped to reduce the probability of false positives when determining the factorial structure of the test.
The second group with 249 participants was submitted to Confirmatory Factor Analysis (CFA) with Weighted Least Square Mean and Variance Adjusted (WLSMV) (Holtmann, Koch, Lochner, \& Eid, 2016) in which models derived from EFA and an alternative one-factor model were tested. Chi square model $\left(\chi^{2}\right)$, Relative Chi square $\left(\chi^{2} / d f\right)$ (Byrne, 2006), comparative fit index (CFI), Tucker-Lewis index (TLI), Standardized Root Mean Square Residual (SRMR) and root mean square error of approximation (RMSEA) (Batista-Fogueta, Manuel, Coenders \& Alonso, 2004, Thompson, 2004) were calculated. Proportion of participants for the conformation of the groups for the EFA and the CFA are within relevant parameters (Boomsma \& Hoogland, 2001; Ferrando \& Anguiano-Carrasco, 2010).

Finally, the third block comprises the analysis of intercorrelations to determine multicollinearity with polychoric correlation, reliability of MMICA with Omega Coefficient $(\omega)$ and a 95\% confidence interval (McDonald, 1999; Ventura-León \& Caycho-Rodríguez, 2017) to identify internal consistency between the item responses. And criterion validity of the test comparing participants with risky alcohol consumption $(n=42)$ and not risky consumption $(n=50)$. All participants with a score equal to or greater than 7 in the AUDIT test were included in the risky alcohol consumption group, whereas the not risky consumption group was created by a random selection among those participants who scored less than 7 in the AUDIT test. $t$ test for independent samples (t) was used; the existence of significant differences $(p<.05)$ is evidence for criterion validity.

The statistical management for preliminary analysis, CFA, reliability and criterion validity was carried out through R language in 3.6.1. version (R Core Team, 2019); while for EFA used Factor version 10.3.01 (Lorenzo-Seva \& Ferrando, 2013).

\section{RESULTS}

\section{Preliminary analysis}

Table 1 shows a homogeneous trend in the responses of the items, leaning to a general sense of disagreement with questions related to intentionality of consumption. In univariate normality analysis, all the items fulfilled this assumption, except for item nine, 
whose values of skewness and kurtosis are outside the range \pm 1.5 . Mardia test shows that multivariate normality assumption is not present because there are statistical significance for skewness and kurtosis $(p<.05)$.

Table 1. Preliminary analysis of MMICA items

\begin{tabular}{|c|c|c|c|c|c|}
\hline & & $M$ & $S D$ & Skew & Kurt \\
\hline \multicolumn{6}{|c|}{ ¿Would you try alcohol if you... } \\
\hline 1 & Could get it without risk? & 2.02 & 1.28 & 0.88 & -0.57 \\
\hline 2 & $\begin{array}{l}\text { Knew how to prepare and } \\
\text { consume it? }\end{array}$ & 1.99 & 1.19 & 0.85 & -0.51 \\
\hline 3 & Could buy it easily? & 2.00 & 1.22 & 0.90 & -0.41 \\
\hline 4 & $\begin{array}{l}\text { Were sure that you will not get } \\
\text { drunk? }\end{array}$ & 2.30 & 1.41 & 0.57 & -1.12 \\
\hline \multicolumn{6}{|c|}{ In your opinion, consuming alcohol... } \\
\hline 5 & $\begin{array}{l}\text { Would allow you to do different } \\
\text { things? }\end{array}$ & 2.14 & 1.30 & 0.74 & -0.73 \\
\hline 6 & $\begin{array}{l}\text { Would release you from } \\
\text { pressures? }\end{array}$ & 2.10 & 1.26 & 0.82 & -0.51 \\
\hline 7 & $\begin{array}{l}\text { Would help you overcome } \\
\text { personal insecurity? }\end{array}$ & 1.98 & 1.22 & 0.96 & -0.27 \\
\hline 8 & $\begin{array}{l}\text { Would help you forget your } \\
\text { sorrows? }\end{array}$ & 2.13 & 1.42 & 1.97 & 8.35 \\
\hline \multirow[t]{2}{*}{9} & $\begin{array}{l}\text { Would help you get your } \\
\text { friends' approval? }\end{array}$ & 1.87 & 1.15 & 1.23 & 0.57 \\
\hline & Mardia test & - & - & $1012.4^{\star \star *}$ & $30.4^{\text {*** }}$ \\
\hline
\end{tabular}

\section{Factor analysis}

Table 2 displays the structural configuration of MMICA, which shows that the test responds to a bifactorial configuration. Initially, both the KMO and Barttlet test showed that item scores have ideal characteristics for an EFA. Similarly, communalities of items display appropriate parameters. In the factor extraction with ULS method and promin rotation, the bifactorial structure of the original model is ideal for Ecuadorian adolescent population. The global explained variance of the MMICA is around $72.1 \%$, with $52.6 \%$ for factor 1 and $19.5 \%$ for factor two.

Likewise, Table 3 presents the results of CFA. Two adjustment models are tested to find out which of them has an acceptable factorial structure. The first model is a two related factors resulting from the referential model and the second one is an alternative unifactorial alternative. In both cases, WLSMV estimation was considered in CFA.

Results of the CFA reveal that the model with the best adjustment is the two-factor model of the MMICA, since the scores of the general adjustment model $\left(\chi^{2}\right)$, relative $(\chi 2 / d f)$ as well as the different adjustment indies (CFI, TLI, SRMR and RMSEA) are within adecuate parameters.

Table 2. Exploratory Factor Analysis of MMICA

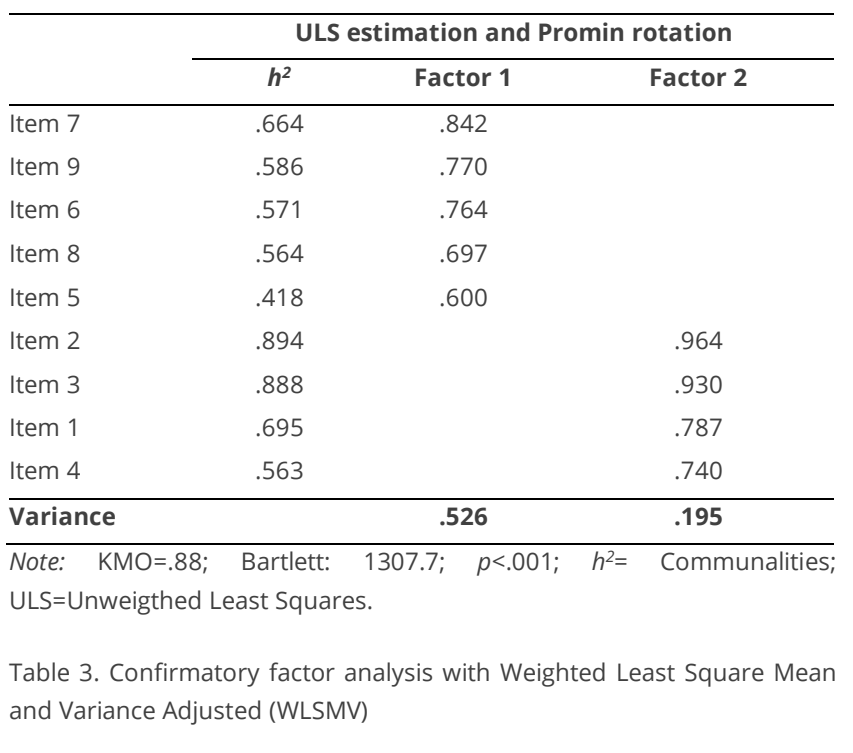

\begin{tabular}{llllllll}
\hline & $\chi^{2}$ & $d f$ & $\chi^{2} / d f$ & CFI & TLI & SRMR & RMSEA \\
\hline $2 \mathrm{FM}$ & $39.9^{* * *}$ & 26 & 1.5 & .98 & .97 & .045 & $.048_{[.011-.077]}$ \\
$1 \mathrm{FM}$ & $198.2^{* * *}$ & 27 & 7.3 & .70 & .61 & .134 & $.166_{[.145-188]}$ \\
\hline Note: ${ }^{* * *} p<.001 ; \chi^{2}=$ Chi square; $d f=$ Degrees of freedom; CFI=Comparative \\
fit index; TLI=Tucker-Lewis Index; SRMR=Standardized root mean square \\
residual; RMSEA=Root mean square error of approximation.
\end{tabular}

Figure 1 also shows that factor 1 (behavioural control) factor loadings are between .69 (item 4) and .89 (item 3); while factor 2 (behavioural beliefs) factor loadings fluctuates between .55 (item 5) and .87 (item 8). The magnitude of the loads reflects the consistency of the items in the proposed model. Finally, the two factors correlate with each other in a moderate and positive way with $r=.48 ; p<.001$.

\section{Intercorrelations, reliability and criterion validity}

In Table 4 analysis of inter-correlations of items of MMICA, indicates that these positively correlate to each other in a low, moderate and high way. The absence of multicollinearity is estimated, since the magnitudes of the correlations between pairs of items are below .9 and it is concluded that they are not redundant with each other. 


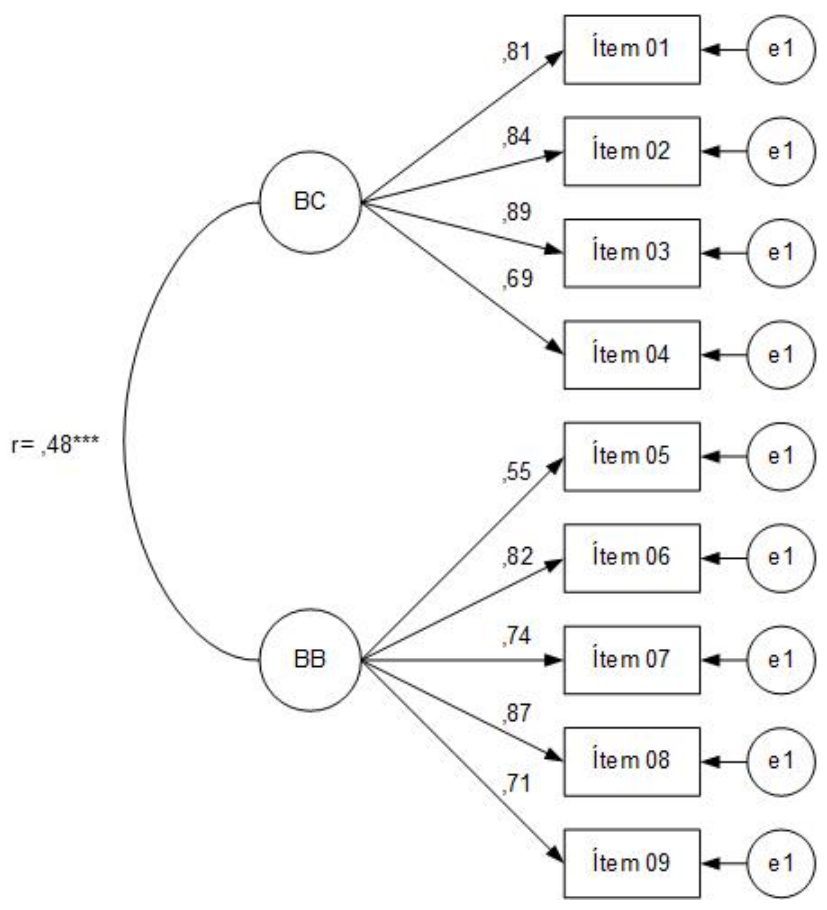

Figure 1. MMICA factor structure. Ellipses represent the constitutive factors. The rectangles to the items and the circles to the errors.

Table 4. Intercorrelations analysis of items of MMICA

\begin{tabular}{|c|c|c|c|c|c|c|c|c|c|}
\hline & 1 & 2 & 3 & 4 & 5 & 6 & 7 & 8 & 9 \\
\hline Item 1 & 1 & & & & & & & & \\
\hline Item 2 & $.82^{* *}$ & 1 & & & & & & & \\
\hline Item 3 & $.77^{* *}$ & $.87^{* *}$ & 1 & & & & & & \\
\hline Item 4 & $.59^{* *}$ & $.69^{* *}$ & $.75^{* *}$ & 1 & & & & & \\
\hline Item 5 & $.36^{* *}$ & $.31^{* *}$ & $.37^{* *}$ & $.32^{* *}$ & 1 & & & & \\
\hline Item 6 & $.32^{* *}$ & $.29^{* *}$ & $.36^{* *}$ & $.28^{* *}$ & $.52^{* *}$ & 1 & & & \\
\hline Item 7 & $.35^{* *}$ & $.28^{\star *}$ & $.33^{* *}$ & $.27^{\star *}$ & $.55^{* \star}$ & $.58^{\star *}$ & 1 & & \\
\hline Item 8 & $.42^{* *}$ & $.41^{* *}$ & $.40^{* *}$ & $.34^{* *}$ & $.45^{* *}$ & $.53^{* *}$ & $.64^{* *}$ & 1 & \\
\hline Item 9 & $.35^{* *}$ & $.34^{* *}$ & $.35^{* *}$ & $.25^{* *}$ & $.46^{* *}$ & $.62^{* *}$ & $.60^{* *}$ & $.59^{* *}$ & 1 \\
\hline
\end{tabular}

Note: ${ }^{*} p<.01$

As observed in Table 5 in the internal consistency analysis, scores and confidence intervals in both Behavioural Control ( $\omega=.90, \quad \mathrm{Cl}_{95 \%[.88-.92])}$ and Behavioural Beliefs ( $\left.\omega=.84, \mathrm{Cl}_{95 \%}[.81-.87]\right)$ factors are high; this shows that MMICA is reliable in terms of internal consistency between items for each constituent factor. In addition, there is criterion validity, because the scores of the MMICA among the group with risky alcohol consumption are much higher than those among the group of not risky alcohol consumption, with significant differences for the factors of Behavioural Control $(t=5.37$; $p<.001)$ and Behavioural Beliefs $(t=4.76 ; p<.001)$.

Table 5. MMICA reliability analysis and criterion validity between risky and not risky alcohol consumers

\begin{tabular}{|c|c|c|c|c|c|c|c|}
\hline & \multirow{2}{*}{$\boldsymbol{\omega}_{\mathrm{Cl} 95 \%}$} & \multicolumn{2}{|c|}{ Risky } & \multicolumn{2}{|c|}{ Not risky } & \multirow{2}{*}{$\mathbf{F}$} & \multirow{2}{*}{$t$} \\
\hline & & $M$ & $S D$ & $M$ & $S D$ & & \\
\hline$B C$ & $.90_{[.88-92]}$ & 12.50 & 4.64 & 7.60 & 4.11 & .046 & $5.37^{\star \star \star *}$ \\
\hline BB & $.84[.81-.87]$ & 15.10 & 5.27 & 9.86 & 5.24 & .012 & $4.76^{\star \star \star}$ \\
\hline
\end{tabular}

Note: $\mathrm{BC}=$ Behavioural control; $\mathrm{BB}=$ Behavioural beliefs; $n_{\text {(risky) }}=42 ; n_{\text {(not risky) }}=$

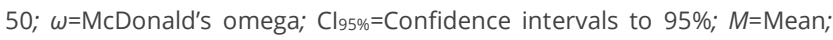
$S D=$ Standard deviation; ${ }^{* * *} p<.001$.

\section{DISCUSSION}

The objectives of this study were to confirm the bifactorial model of MMICA in a sample of Ecuadorian adolescents as well as its reliability and criterion validity between risky and not risky alcohol consumers.

Exploratory factor analysis (EFA) indicates that the instrument explains $72.1 \%$ of the variance of intention towards consumption construct throughout the two proposed factors. In addition, in confirmatory phase (CFA) the bifactorial model is adequate according to the general model $\left(\chi^{2}\right.$ and $\left.\chi^{2} / d f\right)$, as well as to many adjustment indexes (CFI, TLI, RSMR and RMSEA) following criteria and standards considered appropriate for validation (BatistaFogueta, Manuel, Coenders \& Alonso, 2004; Boomsma \& Hoogland, 2001; Byrne, 2006; Ferrando \& AnguianoCarrasco, 2010; Thompson, 2004). Finally in the analysis of intercorrelations and internal consistency, findings indicate that MMICA through is highly reliable $(\omega>.80)$ and consistent, for each of its factors.

The structure and reliability of the MMICA, aside from being optimal for the Ecuadorian population, is similar to previous findings in Mexican adolescents (Vera Noriega et al., 2014) in which the instrument was validated. This indicates that the intention towards consumption construct, intended to be measured, is suited to assess populations that share similar alcohol consumption patterns in spite of its cultural variations. This unlocks the possibility to develop future validation studies in other countries of the region expecting promising results. 
On the other hand, in the analysis of criterion validity, significant differences were found $(p<.05)$ between risky consumers (greater intentionality) and not risky consumers in the two constitutive factors of the MMICA. Although there are no previous referential studies, the evidence points out to the existence of a psychometric segmentation property of the adolescent population associated with alcohol consumption. It also allows corroborating, through Ecuadorian population, the connection between behavioural intention and alcohol consumption behaviour previously researched (Broadwater et al., 2006; Cooke et al., 2016; Glock \& Krolak-Schwerdt, 2013; Hasking \& Schofield, 2015).

With the information reported, we can conclude that MMICA is a reliable and valid instrument for assessing intention towards alcohol consumption in Ecuadorian adolescents. We estimate that current calibration of the test would present less bias in its results (Caycho. 2017; Dominguez-Lara, Merino-Soto \& Navarro-Loli, 2018; Hox, Moerbeek \& Van de Schoot, 2017) and precision assessing intention towards alcohol consumption. Therefore, the results of this work contribute to improve the development of existing measurement instruments on alcohol consumption and related variables, which is scarce and limited in Ecuador and in the region.

From a theoretical approach, the MMICA presents a significant contribution to the theoretical framework of Planned Behaviour (Ajzen, 1985; Fishbein \& Ajzen, 2010; Conner \& Sparks, 2015) and its use in research of behaviours related to alcohol consumption (RodrígueKuri et al., 2007), since it is presented as a solid measuring instrument and adjusted to the current measurement standards. This makes TPB quite useful when proposing scientific evidence about its results and practical applications in the areas of evaluation, diagnosis and intervention. Although studies of this model in Latin America are not widely systematized, abundant evidence (Dempsey et al., 2016; Mankarious \& Kothe, 2015; Norman, 2011; Norman, Webb \& Millings, 2019; Peltzer et al., 2017) points out its effectiveness. Nowadays TPB it is a versatile and booming theory to generate solutions on problems associated with teenagers' alcohol consumption through management of health information, norms of behaviour and individual perceptions (Sheeran et al., 2016; Wigg \& Stafford, 2016).

\section{REFERENCES}

Ajzen, I. (1985). From intentions to actions: A theory of planned behavior. In Action control, 11-39.

Ajzen, I., \& Fishbein, M. (2000). Attitudes and the Attitude-Behavior Relation: Reasoned and Automatic Processes. European Review of Social Psychology, 11(1), 1-33.

Ato, M., López, J., \& Benavente, A. (2013). Un sistema de clasificación de los diseños de investigación en psicología. Anales de Psicología, 29(3), 1038-1059. doi:10.6018/analesps.29.3.178511

Batista-Fogueta, Manuel, J., Coenders, G., \& Alonso, J. (2004). Análisis factorial confirmatorio. Su utilidad en la validación de cuestionarios relacionados con la salud. Medicina Clínica, 122(Supl 1), 21-7.

Boomsma, A., \& Hoogland, J. (2001). The robustness of LISREL modeling revisited. En R. Cudeck, S. Du Toit, \& D. Sörbom (Edits.), Structural equation modeling: present and future. A festschrift in honor of Karl Jöreskog (págs. 139-168). Chicago: Scientific Software International.

Broadwater, K., Curtin, L., Martz, D. M., \& Zrull, M. C. (2006). College student drinking: Perception of the norm and behavioral intentions. $\begin{array}{lll}\text { Addictive } \quad \text { behaviors, } & \text { 34(1), }\end{array}$ doi:10.1016/j.addbeh.2005.05.041

Byrne, B. M. (2006). Structural equation modeling with EQS. Basic concepts, applications, and programming (2nd ed.). Hills Dale, NJ: Lawrence Erlbaum Associates.

Cain, M. K., Zhang, Z., \& Yuan, K. H. (2017). Univariate and multivariate skewness and kurtosis for measuring nonnormality: Prevalence, influence and estimation. Behavior Research Methods, 49(5), 1716 1735. doi:10.3758/s13428-016-0814-1

Caycho, T. (2017). Importancia del análisis de invarianza factorial en estudios comparativos en Ciencias de la Salud. Educación Médica Superior, 31(2), 1-3.

Conner, M., \& Sparks, P. (2015). Theory of planned behaviour and the reasoned action approach. En M. Conner, \& P. Norman (Edits.), Predicting and changing health behaviour: Research and practice with social cognition models (3rd ed., págs. 142-188). Buckingham.

Consejo Nacional de Control de Sustancias Estupefacientes y Psicoactivos [CONSEP]. (2013). IV Estudio Nacional sobre uso de drogas en población de 12 a 65 años del Ecuador. Quito: CONSEP.

Cooke, R., Dahdah, M., Norman, P., \& French, D. P. (2016). How well does the theory of planned behaviour predict alcohol consumption? A systematic review and meta-analysis. Health psychology review, 10(2), 148-167. doi:10.1080/17437199.2014.947547

Dempsey, R. C., McAlaney, J., Helmer, S. M., Pischke, C. R., Akvardar, Y., Bewick, B. M., . . . Van Hal, G. (2016). Normative perceptions of cannabis use among European university students: associations of perceived peer use and peer attitudes with personal use and attitudes. Journal of studies on alcohol and drugs, 77(5), 740-748. doi:10.15288/jsad.2016.77.740

Dominguez-Lara, S., Merino-Soto, C., \& Navarro-Loli, J. (2018). Comparación de coeficientes alfa basada en intervalos de 
confianza. Educación $\quad$ Médica, 19(1), 70. doi:10.1016/j.edumed.2017.03.025

Durán, M., Rodríguez, M., Ferraces, M. J., Río, A., \& Sabucedo, J. M. (2016). Determinantes del mantenimiento del consumo de tabaco: extensión de la Teoría de la Conducta Planificada. Terapia psicológica, 34(1), 15-22.doi:10.4067/S0718-48082016000100002

Ferrando, P. J., \& Anguiano-Carrasco, C. (2010). El análisis factorial como técnica de investigación en psicología. Papeles del Psicólogo, 31(1), 18-33.

Fishbein, M., \& Ajzen, I. (2010). Predicting and changing behavior: the reasoned action approach. New York: Taylor and Francis.

Glock, S., \& Krolak-Schwerdt, S. (2013). Changing Outcome Expectancies, Drinking Intentions, and Implicit Attitudes toward Alcohol: A Comparison of Positive Expectancy-Related and Health-Related Alcohol Warning Labels. Applied Psychology: Health and Well-being, 5(3), 332-347. doi:10.1111/aphw.12013

Guzmán Facundo, F. R., García Salas, B. A., Aguilar, L. R., \& Alonso Castillo, M. M. (2014). Actitud, norma subjetiva y control conductual como predictores del consumo de drogas en jóvenes de zona marginal del norte de México. Frontera norte, 26(51), 53-74. doi:10.4067/s0717-95532012000100006

Hasking, P., \& Schofield, L. (2015). Examining alcohol consumption with the theory of planned behaviour: Do health and alcohol knowledge play a role? Psychology, health \& medicine, 20(7), 838-845. doi:10.1080/13548506.2014.969748

Holtmann, J., Koch, T., Lochner, K., \& Eid, M. (2016). A comparison of ML, WLSMV, and Bayesian methods for multilevel structural equation models in small samples: A simulation study. Multivariate behavioral research, 51(5), 661-680. doi:10.1080/00273171.2016.1208074

Hox, J. J., Moerbeek, M., \& Van de Schoot, R. (2017). Multilevel analysis: Techniques and applications (3er ed.). New York: Routledge.

Kuntsche, E., Kuntsche, S., Thrul, J., \& Gmel, G. (2017). Binge drinking: Health impact, prevalence, correlates, and interventions. Psychology \& Health, 32, 976-1017. doi: 10.1080/08870446.2017.1325889

Lorenzo-Seva, U. (1999). Promin: a method for oblique factor rotation. Multivariate Behavioral Research, 34, 347-356.

Lorenzo-Seva, U., \& Ferrando, P. (2013). FACTOR 9.2 A Comprehensive Program for Fitting Exploratory and Semiconfirmatory Factor Analysis and IRT Models. Applied Psychological Measurement, 37(6), 497-498.

Mankarious, E., \& Kothe, E. (2015). A meta-analysis of the effects of measuring theory of planned behaviour constructs on behaviour within prospective studies. Health psychology review, 9(2), 190-204. doi:10.1080/17437199.2014.927722

Mardia, K. (1970). Measures of Multivariate Skewness and Kurtosis with Applications Measures of Multivariate Skewness and Kurtosis with Applications. Biometrika, (57), 519. doi:10.2307/2334770

McDonald, R. P. (1999). Test theory: A unified treatment. Mahwah: Lawrence Erlbaum Associates, Inc.
Moreta-Herrera, R., Almache-Moya, A., Vargas-Espín, A., \& Vaca-Quintana, D. (2019). Levels and Patterns of Alcohol Consumption: a Descriptive Study in Ecuadorian Teenagers. International Journal ofj Mental Health Addiction, online version. doi:10.1007/s11469-019. $\underline{00197-9}$

Moreta-Herrera, R., Ilaja-Verdesoto, B., Mayorga-Lascano, M., LeónTamayo, L., \& López-Castro, J. (2018b). Actitudes y disposición personal ante el consumo y exposición a sustancias en adolescentes del Ecuador. Health \& Addictions/Salud y Drogas, 18(2), 217-226. doi:10.21134/haaj.v18i2.383

Moreta-Herrera, R., Mayorga-Lascano, M., León-Tamayo, L., \& IlajaVerdesoto, B. (2018a). Consumo de sustancias legales, ilegales y fármacos en adolescentes y factores de riesgo asociados a la exposición reciente. Health \& Adictions/Salud y Drogas, 18(1), 39-50. doi: 10.21134/haaj.v18i1.333

Norman, P. (2011). The theory of planned behavior and binge drinking among undergraduate students: Assessing the impact of habit strength. Addictive Behaviors, 36, 502-507. doi:10.1016/j.addbeh.2011.01.025

Norman, P., Webb, T. L., \& Millings, A. (2019). Using the theory of planned behaviour and implementation intentions to reduce binge drinking in new university students. Psychology \& Health, 34(4), 478-496. doi:10.1080/08870446.2018.1544369

Pan American Health Organization [PAHO]. (2015). Regional Status Report on Alcohol and Health in the Americas. Wahington, DC: PAHO-WHO.

Paqui Baho, K. (2017). Funcionalidad familiar y su relación con el consumo de alcohol en adolescentes de Bachillerato de la Zona 7 Ecuador. 2016 (Master's thesis). Loja: Universidad Nacional de Loja.

Peltzer, R. I., Conde, K., Biscarra, M. A., Lichtenberger, A., \& Cremonte, M. (2017). Ampliando la evidencia para la Teoría de la Conducta Planeada: predicción del consumo episódico de alcohol en jóvenes mujeres y varones de Argentina. Health and Addiction/Salud y drogas, 17(2), 159-167. doi:10.21134/haaj.v17i2.323

Pérez, E. R., \& Medrano, L. (2010). Análisis factorial exploratorio: bases conceptuales y metodológicas. Revista Argentina de Ciencias del Comportamiento, 2(1), 58-66.

R Core Team. (2019). R: A language and environment for statistical computing. , R Foundation for Statistical Computing. Vienna, Austria: R Foundation for Statistical Computing.

Rodríguez-Kuri, S. E., Diaz-Negrete, D. B., Gracia-Gutiérrez de Velasco, S. E., Guerrero-Huesca, J. A., \& Gómez-Maqueo, E. L. (2007). Capacidad predictiva de la Teoría de la Conducta Planificada en la intención y uso de drogas ilícitas entre estudiantes mexicanos. Salud Mental, $30(1), 68-81$.

Sheeran, P., Maki, A., Montanaro, E., Avishai-Yitshak, A., Bryan, A., Klein, W. M., . . . Rothman, A. J. (2016). The impact of changing attitudes, norms, and self-efficacy on health-related intentions and behavior: a meta-analysis. Health Psychology, 35(1), 148-167. doi:10.1080/17437199.2014.947547 
Thompson, B. (2004). Exploratory and confirmatory factor analysis: Understanding concepts and applications. Washington, District of Columbia: American Psychological Association.

Ventura-León, J., \& Caycho-Rodríguez, T. (2017). El coeficiente Omega: un método alternativo para la estimación de la confiabilidad. Revista Latinoamericana de Ciencias Sociales, Niñez y Juventud, 15(1), 625-627.

Vera Noriega, J., Tánori Quintana, J., Valdés Cuervo, Á., Martínez Ortega, L., \& Martínez, E. (2014). Modelo de medición de la intención de consumo de alcohol en adolescentes. Interamerican Journal of Psychology, 48(3), 327-339.

Wigg, S., \& Stafford, L. D. (2016). Health Warnings on Alcoholic Beverages: Perceptions of the Health Risks and Intentions towards Alcohol Consumption. PLOS ONE, 11(4), e0153027. doi:10.1371/journal.pone.0153027

World Health Organization [WHO]. (2014). Global status report on alcohol and health 2014. Geneva: WHO Press. 


\section{¿Probarías bebidas alcohólicas desconocidas...}

$1 \quad$ ¿Si pudieras adquirirlo sin correr riesgo?

$2 \quad$ ¿Si supieras como prepararlo y consumirlo?

$3 \quad$ ¿Si pudieras conseguir fácilmente?

$4 \quad$ ¿Si estuvieras seguro de que no te vas a emborrachar?

En tu opinión ¿Consumir el alcohol...

5 te permitiría hacer cosas diferentes?

$6 \quad$ te liberaría de las presiones?

7 te permitiría superar la inseguridad?

8 te serviría para desahogar tus penas?

9 te ayudaría a tener la aceptación de tus amigos? 